\title{
STRATEGI BUMD JAKARTA DALAM MENDUKUNG KEBIJAKAN PROGRAM KETAHANAN PANGAN
}

\section{STRATEGY Of BUMD JAKARTA IN SUPPORTING FOOD SECURITY PROGRAM}

\author{
Yurianto* \\ Widyaiswara Ahli Madya, BPSDM Provinsi DKI Jakarta \\ *E-mail corresponding: yurimerdeka@gmail.com
}

\begin{abstract}
ABSTRAK
Pangan adalah kebutuhan dasar manusia yang paling utama dan pemenuhannya merupakan bagian dari hak asasi manusia. BUMD mempunyai peran yang strategis dan sentral dalam pengelolaan ketahanan pangan DKI Jakarta. Tujuan kajian adalah menyusun strategi aksi BUMD klaster pangan dan usaha perpasaran dalam melakukan aksi korporasinya mengelola program ketahanan pangan Jakarta. Analisis yang digunakan pendekatan APKL, EFAS dan IFAS, SWOT, dan metode Mc. Namara. Kesimpulannya bahwa BUMD Perumda Pasar Jaya, PD Dharma Jaya dan PT Food Station Tjipinang mempunyai fungsi yang sentral dan strategis dalam implementasi pengelolalan program ketahanan pangan di DKI Jakarta. Strategi yang tepat adalah strategi Peningkatan Kolaborasi Seluruh Pemangku Kepentingan Dengan Prinsip Kemitraan. Disarankan diperlukan pengembangan sumber daya manusia dan kerja kolaboratif dan koordinatif antar ketiga BUMD.
\end{abstract}

Kata kunci: pangan, ketahanan, strategi, BUMD, Jakarta. SWOT.

\begin{abstract}
Food is the most important basic human need and its fulfillment is part of human rights. BUMD (a company owned by the DKI Jakarta Provincial Government) has a strategic and central role in the management of food security in DKI Jakarta. The purpose of the study is to formulate an action strategy for BUMD food clusters and market businesses in carrying out their corporate actions in managing Jakarta's food security program. The analysis used APKL, EFAS and IFAS, SWOT, and Mc Namara methods.. The conclusion is that BUMD Perumda Pasar Jaya, PD Dharma Jaya and PT Food Station Tjipinang have a central and strategic function in the implementation of food security program management in DKI Jakarta. The right strategy is the strategy of Enhancing Collaboration of All Stakeholders With Partnership Principles. It is recommended that the development of human resources and collaborative and coordinative work between the three BUMDs are needed.
\end{abstract}

Keywords: food, security, strategy, BUMD, Jakarta, SWOT.

\section{PENDAHULUAN}

Salah satu isu penting dalam pembangunan ekonomi Jakarta adalah isu ketahanan pangan. Sebagamana dilansir oleh kontan .com bahwa bahwa
98 persen pasokan pangan di DKI ini bergantung kepada daerah produsen. Kondisi ini lah yang perlu penanganan serius dari selaruh pemangku kepentingan pembangunan ketahanan 


\section{STRATEGI BUMD JAKARTA DALAM MENDUKUNG KEBIJAKAN PROGRAM \\ KETAHANAN PANGAN}

Yurianto

pangan Jakarta, baik bagi institusi pemerintah maupun non pemerintah.

Hal ini sebagaimana dinyatakan dalam ketentuan bahwa pangan adalah kebutuhan dasar manusia yang paling utama dan pemenuhannya merupakan bagian dari hak asasi manusia yang dijamin di dalam Undang-Undang Dasar Negara Republik Indonesia Tahun 1945 sebagai komponen dasar untuk mewujudkan sumber daya manusia yang berkualitas ( UU No 18 tahun 2012 tentang Pangan). Ditambahkan lagi bahwa negara berkewajiban mewujudkan ketersediaan, keterjangkauan, dan pemenuhan konsumsi Pangan yang cukup, aman, bermutu, dan bergizi seimbang, baik pada tingkat nasional maupun daerah hingga perseorangan secara merata di seluruh wilayah Negara Kesatuan Republik Indonesia sepanjang waktu dengan memanfaatkan sumber daya, kelembagaan, dan budaya local

Berkaitan dengan tingkat ketergantungan DKI Jakarta akan pangan sangat beralasan. Lahan di DKI Jakarta sangat terbatas sehingga produksi pangan Jakarta rendah. Keterbatasan ini meliputi keterbatasan daya dukung lahan, baik pertanian, perikanan maupun peternakan, untuk menyuplai kebutuhan DKI Jakarta. Ditambah lagi, ada kecenderungan permintaan pangan DKI Jakarta meningkat terus. Sebagai contoh komoditas beras. Kebuthan beras Jakarta dipenuhi dari beberapa daerah lain. Kebutuhan beras Jakarta disuplai dari Jawa Barat, Jawa Tengah, Jawa Timur, Sulawesi Selatan, Lampung, dan Sumatera Selatan. Sementara itu, daging sapi disuplai dari Jawa Tengah, Jawa Timur, Yogyakarta, Bali, Nusa Tenggara Timur, Lampung, dan impor dari luar negeri.

Dengan demikian diperoleh informasi bahwa isu ketahanan pangan di DKI Jakarta cukup rumit dan kompleks. Oleh karena itu, dalam penanganan isu ini dibutuhkan seleksi strategi yang tepat efisien dan efektif. Yang perlu menjadi perhatian kita adalah bahwa pengelolaan ketahanan pangan Jakarta tidak bisa hanya dilakukan oleh pemerintah tetapi harus dilakuikan juga oleh institusi nonpemerintah.

Khusus dari lingkungan Pemerintah Provinsi DKI Jakata, salah satu institusi yang strategis untuk menangani ini adalah BUMD. Alasannya adalah bahwa BUMD merupakan perusahaan atau Lembaga yang dimiliki Pemerintah Provinsi DKI Jakarta. BUMD juga mempunyai tujuan untuk meningkatkan pembangunan ekonomi di daerah. Selain itu, beberapa BUMD Jakarta dibentuk khusus untuk menangani pengelolaan ketersediaan pangan di Jakarta, yaitu BUMD Klaster Pangan dan Usaha Perpasaran. BUMD yang termasuk dalam klister ini adalah Perusahaan Umum 
Daerah (Perumda) Pasar Jaya,

Perseroan Terbatas (PT) Food Station

Tjipinang, dan Perusahaan Daerah (PD)

Dharma Jaya. Untuk selanjutnya klaster ini akan disebut dengan BUMD klaster Pangan.

BUMD Mempunyai peran yang sangat penting dalam pembangunan ekonomi daerah. Hal ini jika dilihat dari tujuan didirkannya BUMD itu sendirti. Tujuan pendirian BUMD sesuai dengan perundangan Nomor 23 tahun 2014 bahwa pendirian BUMD yaitu a. memberikan manfaat bagi perkembangan perekonomian Daerah; b. menyelenggarakan kemanfaatan umum berupa penyediaan barang dan/atau jasa yang bermutu bagi pemenuhan hajat hidup masyarakat sesuai kondisi, karakteristik dan potensi Daerah yang bersangkutan berdasarkan tata kelola pemsahaan yang baik; dan $c$. memperoleh laba dan/atau keuntungan

Dengan demikian, BUMD klaster pangan ini mempunyai peran yang strategis dan sentral dalam pengelolaan ketahana pagan DKI Jakarta. Menurut Aisyah (2020) bahwa Ketahanan Pangan merupakan kondisi terpenuhinya pangan bagi rumah tangga yang tercermin dari ketersediaan pangan yang cukup, baik jumlah, maupun mutunya, aman, merata, dan terjangkau. Dengan demikian BUMD klaster pangan ini juga diarahkan untuk mengelola ketahanan pangan termasuk di dalamnya adalah ketersediaaan, keterjangakuan, dan kesehatan pangan di DKI Jakarta. Berkaitan dengan isu ini pertanyaan yang mengemuka adalah bagaimana strategi BUMD klaster pangan DKI Jakarta dalam rangka mengelola kebijakan ketahanan pangan di DKI Jakarta.

Dengan mendasarkan pada isu tersebut dan dengan memperhatikan peran BUMD klaster pangan tersebut, maka diperlukan suatu kajian yang komprehensif untuk menyusun strategi yang digunakan dalam pengelolalan ketahanan pangan di DKI Jakarta. Untuk itulah maka tujuan dari kajian ini adalah:

1. Mendeskripsikan korporasi BUMD Klaster Usaha Perpasran dan Pangan Jakarta

2. Mengidentifikasi potensi BUMD Klaster Pangan dengan pendekatan faktor Internal dan faktor eksternal.

3. Menyusun matriks IFAS dan EFAS pada BUMD Klaster Pangan dalam konteks ketahanan pangan

4. Menyusun koordinat caretisius matriks SWOT strategi BUMD klaster pangan dalam mengelola program ketahanan pangan.

5. Menyusun strategi aksi BUMD klaster pangan dalam melakukan aksi korporasinya mengelola program ketahanan pangan Jakarta. 
Dengan mendasarakan pada tujuan tersebut maka tidak diragukan lagi bahwa BUMD itu penting dan strategis dalam pembangunan ekonomi. BUMD dengan karateriistiknya akan berperan aktif dalam berkonrtibusi dalam membanugn DKI Jakarta sesuai dengan peran dan funsginya. Namun untuk melakukan dan memerankan fungsinya tersbeut diperlukan strategi yang tepat sesuai dengan situasi dan kondisi lingkungan .

Sesuai dengan arahan RPJMD DKI Jakarta 2017- 2022, untuk memudahkan dalam pembinaan dan pengembangan, BUMD DKI Jakarta kelompokkan menjadi 9 (Sembilan) kalster. Klaster usaha yang membidangi pembinaan dan pengembangna ketahanan paangan adlaah klister usaha pangan dan perpasaran. Klister ini meliputi tiga BUMD , yaitu PT. Food Station Tjipinang Jaya (99.8 persen), PD. Dharma Jaya dan Perumda Pasar Jaya.

\section{Regulasi di Pemerintah Proviisi} DKI Jakarta bahwa tujuan utama program ketahanan pangan pada dasarnya adalah untuk meningkatkan kesejahteraan masyarakat. Melalui pemeliharan dan pengelolaan ketahananan pangan. Arti dari ketahanan pangan adalah kondisi terpenuhinya pangan bagi setiap masyarakat yang tercermin dari tersedianya pangan yang cukup, baik jumlah maupun mutunya, aman, merata, terjangkau, dan berbasis pada keragaman sumber daya lokal.

Ketahanan pangan secara konsep mempunyai pengertian bahwa pangan adalah kondisi terpenuhinya pangan bagi negara sampai dengan perseorangan, yang tercermin dari tersedianya Pangan yang cukup, baik jumlah maupun mutunya, aman, beragam, bergizi, merata, dan terjangkau serta tidak bertentangan dengan agama, keyakinan, dan budaya masyarakat, untuk dapat hidup sehat, aktif, dan produktif secara berkelanjutan

Selain alasan tersebut teradapat beberapa alasan penting lagi mengapa pangan menjadi penting dalam pembangunan ekonomi suatu negara. Kemandirian Pangan adalah kemampuan negara dan bangsa dalam memproduksi Pangan yang beraneka ragam dari dalam negeri yang dapat menjamin pemenuhan kebutuhan Pangan yang cukup sampai di tingkat perseorangan dengan memanfaatkan potensi sumber daya alam, manusia, sosial, ekonomi, dan kearifan lokal secara bermartabat. Menurut Munir (2017) bahwa bagi praktisi di dunia bisnis, khususnya perusahaan multibisnis diperlukan suatu pemahaman mengenai kreasi nilai dan faktor-faktor yang berperan penting dalam prosesnya. 
Hal ini penting untuk meningkatkan kinerja perusahaan. Untuk itu BUMD juga dituntut untuk berkreaasi dan berinovasi dalam melakukan aksi korporasinya untuk mewujudkan yang telah ditetapkan.

\section{METODE PENELITIAN}

Secara teori bahwa metode penelitian kualitatif adalah metode penelitian yang berlandaskan pada filsafat postpositivisme (Sugiyono,2011). Pendekatan ini digunakana untuk meneliti pada kondisi obyek yang alamiah. Artinya bahwa obyek yang diteliti didekati secara apa adanya tidak ada perlakuan khusus jadi benar benar natural. Oleh karena itu maka posisi peneliti menjadi instrument kunci. Kualitas hasil dari kajian ini sangat tergantung dari kualitas peneliti.

Dalam hal ini kajian dilakukan secara pendekatn kualitatif deskriptif. Dalam kajian ini data diperoleh dari wawancara langusng dengan para pemangku kepentingan. Selain itu juga dilakukan secara purposive dengan pendekatan Forum Group Discussion (FGD). Kegiatan ini dimaksudkan agar data dapat diperoleh lebih berkualitas. Selain itu, dengan pendekatan ini data akan lebih spesifik dan seusai dengan inti kajian. Alasanya adalah dengan FGD informasi tentang permasalahan akan bersifat lokal dan spesifik.
Sedangkan data seconder dipeoleh dari dokumentasi yang diperoleh dari BP BUMD dan dokumen dari laman resmi BUMD klaster Pangan dan usaha perpasaran. Data yang teleh tersusun diseleksi dan dikelompokan sesuai dengan tujuan analisis.

Dengan data yang demikian maka diharapkan kajian kan lebih berkualitas dan sesuai dengan tujuan kajian. Selanjutnya untuk analisis digunakan pendekatan Aktual, Problematika, Kekhalayakan, layak (APKL), matriks EFAS dan IFAS, SWOT, dan metode tapisan Mc. Namara.

\subsection{Pendekatan APKL}

Dalam penelitian ini untuk menyeleksi suatu isu digunkan pendaktan APKL. Pendekatan ini pada prinsipnya adalah menguji kelayakan suatu isu untuk dicarikan solusinya dalam kegiatan aktualisasi. Selanjutnya bahwa penetapan nilai untuk setiap isu didasarkan pada diskusi yang melibatkan para penentu kebijakan pada BUMD cluster pangan dan usaha perpasaran, dan organisasi perangkat daerah di lingkungan Pemerintah Provinsi DKI Jakarta.

Tahap identifikasi masalah dalam kajian ini digunaka metode Aktual, Problematika, Khalayak, dan Layak (APKL). Dari beberapa isu diidentifikasi dan kemudian diseleksi dengan menggunakan metode APKL. Dengan isu 
yang sama, Novian, Maha, dan Arif (2021) juga menggunakan metode ini dalam mengidentifikasi maslah optimtalisasi pemberlajaran masa Pandemic 19.

Selanjutnya dikatakan bahwa metode APKL ini digunakan dalam mengidentifikasi masalah metode ini operasionalnya melalui pemilihan masalah yang didasarkan pada penilaian. Penilaian terhadap tingkat aktualitas, problematika, khalayak dan layak menggunakan skala 1-5. Arti angka ini adalah bahwa angka 1 (satu) menunjukkan tingkatan rendah dalam hal prioritasnya sedangkan angka 5 (lima) menunjukan tingkatan tinggi prioritaswnya untuk diselesaikan.

2.2. Analisis Strength, Weakness, Opportunities and Threat (SWOT)

Pada dasarnya analisis SWOT digunakan untuk identifikasi berbagai factor secara sitematis unutk merumuskan strategi organisasi (Rangkuti 2001). Analisis ini berdasarkan logika yang dapat memaksimalkan kekuatan dan peluang namun secara bersamaan dapat meminimalkan kelemahan dan ancaman. Secara terinci masing-masing faktor tersebut dapat dijelaskan sebagai berikut.

Kekuatan adalah factor yang dimiliki oleh perusahaan. Pada langkah operasional dilakukan analisis tentang kelebihan yang dimiliki perusahaan. Sedangkan Kelemahan (Weakness) adalah factor yang secara intrinsic dimiliki oleh organisasi dalam pencapaian tujuan. Dalam hal identifikasi kelemahan suatu organisasi dapat melakukan langkah komparasi dengan pesaing.

Sedangkan Peluang (Opportunity) adalah kesempatan yang dimiliki oleh organisasi. Faktor ini pada umumnya ditemukan pada awal membangun bisnis. Ini karena bisnis dibentuk berdasarkan peluang atau kesempatan untuk menghasilkan keuntungan. Sedangkan Ancaman (Threats) adalah sesuatu yang datang dari luar dan diperkirakan akan menjadi penghalang laju orgnaisasi pada saat organisasi akanmencpai tujuannya. Analisis terhadap unsur ancaman sangat penting karena menentukan apakah bisnis dapat bertahan. . Mendasarkan analisis ini maka secara diagramatik dapat digambarkan dengan diagram kartesius: Opportunities Weaknesses Strengths dan Threats sebagai berikut: 


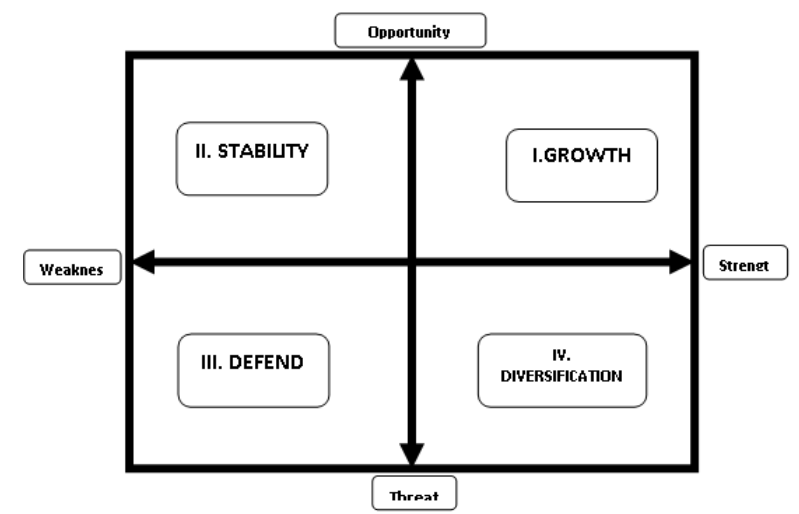

Gambar 1. Diagram Kartesius untuk SWOT

Gambar 1. di atas merupakan diagram kartesius yang merupakan metode untuk menentukan kuadran yang tepat. Untuk itu maka perlu dihitung selisih dari subtotal faktor strengths dengan weaknesses (titik pertama) dan selisih dari subtotal faktor opportunities dengan threats (titik kedua).

Menurut Anggraeni, Sunarti dan Mawardi (2017) bahwa Kuadran I : Merupakan situasi yang sangat menguntungkan. Perusahaan tersebut memiliki peluang dan kekuatan sehingga dapat memanfaatkan peluang yang ada. Strategi yang harus diterapkan dalam kondisi ini adalah mendukung kebijakan pertumbuhan yang agresif. (Growth oriented strategy). Sedangkan Kuadran II : Meskipun menghadapi berbagai ancaman, perusahaan ini masih memiliki kekuatan dari segi internal. Strategi yang harus diterapkan adalah menggunakan kekuatan untuk memanfaatkan peluang jangkapanjang dengan cara strategi diversifikasi (produk/jasa).

Kuadran III : Perusahaan menghadapi peluang pasar yang sangat besar, tetapi dilain pihak, ia menghadapi beberapa kendala/kelemahan internal. Fokus perusahaan ini adalah meminimalkan masalah-masalah internal perusahaan sehingga dapat merebut peluang pasar yang lebih baik. Sedangkan kuadran IV merupakan situasi yang sangat tidak menguntungkan, perusahaan tersebut menghadapi berbagai ancaman dan kelemahan internal.

\subsection{Pendekatan EFAS dan IFAS}

Langkah selanjutnya adalah dengan menggunakan table EFAS dan IFAS. Tabel EFAS Tabel EFAS terdiri dari beberapa kolom. Untuk menyusun tabel EFAS, terlebih dahulu dilakukan identifikasi lingkungan eksternal dan eksternal.

Dalam mengisi tabel EFAS dan IFAS caranya dengan mengisi bobot 


\section{STRATEGI BUMD JAKARTA DALAM MENDUKUNG KEBIJAKAN PROGRAM \\ KETAHANAN PANGAN}

Yurianto

antara 0 dan 1 . Selanjutnya diisikan dari tingkat rating kepentingannya dengan angka peringkat 1,0 (burutk.poor) sampai sampai 4,0 ( sangat baik/outstanding) Rangkuty ( 2001)

$$
\text { Selanjutnya dilakukan }
$$
pengambaran grafik kartesius unutk menentukan kuadaran dari organisasi uang kita susun. Cara menentukan kuadran yang tepat, maka perlu dihitung selisih dari subtotal faktor strengths dengan weaknesses (titik pertama) dan selisih dari subtotal faktor opportunities dengan threats (titik kedua).

Jika hasil selisih dari subtotal faktor strengths dengan weaknesses adalah positif (+), maka titik pertama akan berada di sisi garis horizontal sebelah kanan titik 0 . Jika hasilnya negatif (-), maka titik pertama akan berada di sisi garis horisontal sebelah kiri titik 0 . Jika hasil selisih dari subtotal faktor opportunities dan threats adalah positif $(+)$, maka titik kedua akan berada di sisi garis vertical di bawah 0 . Akhirnya akan ada dua titik yang nantinya akan menentukan kuadran.

Dari hasil perhitungan operasional tersebut akan diperoleh kuadaran atau posisi dari oragnasisasi. Letak posisi ini akan menentukan strategi pengembangan organisasi. Oleh karena itu, kemudaian dilakukan analisis dan penyusunan strategi untuk memperoleh tujuan yang telah dirumuskan dengan baik dan tepat.
2.4. Matode Analisis Alternatif Solusi Mc Namara

Metode ini digunakan untuk melakukan pemilihan strategi operasional yang mana yang patut dan tepat dipilih, Adapun kriteria dalam hal ini adalah efisiensi, efektivitas dan kemudahan. Masing masing anternatif dinilai dengan skore antara 1 ( rendah) sampai dengan 4 ( paling baik). Kemudiaan dari angka ini dijumlahkan. Angka tertinggi merupakan angka yang paling tepat untuk digunakan dalam rangka implementatif strategi operasional BUMD Pangan dalam implementasi program ketahanan pangan di DKI Jakarta.

\section{HASIL DAN PEMBAHASAN \\ Profil BUMD Klaster Usaha Perpasaran dan Pangan}

BUMD Klaster pangan terdiri dari Perumda Pasar Jaya, PT Food Station Tjipinang dan PD Dharma Jaya. PT Food Station Tjipinang Jaya dimiliki sebeasr 99.98 persen dari total saham. selanjutnya PD Dharma Jaya dimiliki 100 persen dan Perumda Pasar Jaya dimiliki Pemerintah Provinsi DKI Jakarta 100 persen. .

BUMD klister pangan memiliki misi ganda. Misi pertama BUMD sebagai Badan Usaha yang berorientasi korporasi sehingga tujuan utama adalah memperoleh keuntungan. Misi kedua 
BUMD sebagai badan usaha untuk misi pelayanan publik dan percepatan pembangunan.

Pada awalnya, Perusahaan Daerah Pasar Jaya didirikan berdasarkan Keputusan Gubernur Kepala Daerah Khusus Ibukota Jakarta No. Ib.3/2/15/66 pada tanggal 24 Desember 1966. Kemudian pengesahan oleh Menteri Dalam Negeri lewat Keputusan No. Ekbang 8/8/13-305 tanggal 23 Desember 1967.

Tugas Pokok Perumda Pasar Jaya adalah melaksanakan pelayanan umum dalam bidang pengelolaan area pasar, membina pedagang pasar, ikut membantu stabilitas harga dan kelancaran distribusi barang dan Jasa. Dalam melaksanakan tugas pokok tersebut Perumda Pasar Jaya mempunyai fungsi antara lain:

- Pengawasan dan pengendalian pemanfaatan area pasar

- Bantuan terhadap stabilitas harga barang

- Bantuan terhadap ketersediaan dan kelancaran distribusi barang dan jasa

- Pelaksanaan dan pengembangan kerjasama, dan

Berbeda dengan Perumda Pasar Jaya, BUMD Perusahan Daerah (PD) Dharma Jaya lebih focus pada bisnis distribusi daging dan ayam. BUMD ini dimiliki oleh Pemrintah Pronvi DKI Jakarta.
BUMD mempunya beberapa bidang usaha. Bidang usaha ini meliputi bidang perdagangan dan industri daging.

Tugas utama PD Dharma Jaya adalah membantu dan menunjang kebijaksanaan umum Pemerintah Provinsi DKI Jakarta dalam rangka ketahanan pangan dan meningkatkan kesejahteraan masyarakat, khususnya produk hewani dan petani ternak.

Dalam melakukan usahanya PD Dharma Jaya memiliki unit usaha yang dapat menunjang terlaksananya target tersebut, Unit usaha tersebut adalah Unit Usaha Penggemukan. Unit usaha penggemukan terbagi menjadi dua, yaitu pembibitan dan penggemukan. Selain itu, PD Dharma Jaya mempunyai Unit Usaha Rumah Potong Hewan.

Dalam hal ini PD Dharma Jaya memiliki beberapa Rumah Potong Hewan, dengan kapasitas 100 ekor per jam. Rumah potong Hewan ini dilengkapi dengan teknologi terkini dalam proses pemotongan hewan. Sampai saat in Rumah Potong Hewan milik PD Dharma Jaya telah mendapatkan sertifikasi halal dari MUI, dan senantiasa dalam pengawasan dan bimbingan dari MUI.

Selain itu, PD Dharma Jaya juga mempunyai Unit Usaha Produksi. Unit usaha ini mencacah dan mengemas daging hewan yang telah dipotong di $\mathrm{RPH}$. Bagian produksi membuat kemasan daging sesuai pesanan para 
pelanggan. Bagian daging sapi dikemas berdasarkan jenis daging.

Hampir mirip dengan PD Dharma Jaya, bidang usaha PT Food Station Tjipinang adalah jasa/pergudangan. Visi BUMD ini adalah menjadi Pusat Informasi dan Perdagangan Bahan Pangan Asia Tenggara. Adapun misinya antara lain adalah

- Membangun dan menyelenggarakan serta mengelola fasilitas-fasilitas yang berhubungan dengan food station;

- Membangun dan menyelenggarakan sentra perdagangan bahan kebutuhan pokok makanan;

- Mengadakan dan menyalurkan serta menjaga stabilitas supplai, distribusi, dan harga bahan pangan pokok;

- Membangun kawasan pangan melalui kerjasama kemitraan untuk menjamin suplai beras ke pasar Induk Cipinang;

Berbeda dengan PD Dharma Jaya, Salah satu usaha BUMD PT Food Station Tjipinang (PT. FS) adalah distribusi beras untuk wilayah DKI Jakarta. Dalam kontek ini termasuk distirbusi beras untuk membantu program Pemerintah Provinsi DKI Jakarta dalam mewujudkan visi dan misi.

Sebagai contoh dalam hal beras bantuan sosial PT FS menyalurkan ke masyarakat DKI Jakarta. Kualitas Beras yang disalurkan adalah beras premium dengan standar Peraturan Menteri Pertanian. Untuk maksud efektivitas dan efisiensi dalam kerangka kolaboraasi, selama penyaluran PT. FS bekerja sama dengan pelaku usaha di daerah.

Dalam kerangaka kolaborasi dan pengembangan usahanya, PT Food Station Tjipinang Jaya juga bekerja sama dengan petani dari berbagai daerah seperti Cilacap, Indramayu, Karawang, Ngawi, Lampung Tengah, Pringsewu hingga Kabupaten Bekasi. Rencanaya PT Food Statiaon Tjipinang lebih mengeolah ke hulu agar cadangan stok untuk Jakarta bisa dikendalikan,

\section{Analisis Kajian APKL,}

Isu yang dihadapi BUMD sektor pangan dalam implementasi strategi pengelolaan ketahanan pangan sangat bervariasi. Terlebih lagi kebijakan seperti ini termasuk kebijakan publik. Dalam hal public, Winarno (2014) mengatakan bahwa dalam perumusan masalah publik tidak bisa dilepaskan dari dua hal. Yang pertama adalah bahwa kelompok yang merumuskan masalah tersebut sangat sentral. Jadi kualitas suatu kebijakan publik sangat tergantung dari siapa yang merumuskan. Yang kedua adalah bahwa kebijakan publik sifatanya sangat kompleks. Untuk diperlukan kehati hatian dalam proses perumsuan kebijakan yang menyanhgkut publik. 
Untuk itulah dalam hal ini dalam kerangka strategi mana yang dipakai oleh BUMD Klaster Pangan dalam merespon program ketahanan pangan perlu pendaktan yang tepat. Dalam kontek didekati dengan focus pada pendekatan manajemen dalam pengelolaan ketahanan pangan. Pendekatan yang menjadi perhatian dalam hal ini meliputi

Strategi Aksi Korporasi Ketahanan Pangan, Strategi Penyusunan Strategi Perencanaan Ketahanan Pangan,
Strategi Penyusunan Strategi Evaluasi Ketahanan Pangan.

Selanjutnya mengingat masih terdapat tiga isu maka diperlukan pemilihan isu yang sangat prioritas. Dalam kontek ini digunakan pendekatan dengan kriteria yang paling actual, problematic dan berdampak luas, dan layak untuk dilakukan. Untuk keperluan ini digunakan pendekatan merode APKL. Hasil dari pendekatan metode APKL ini adalah sebagai berikut.

Tabel. 1. Analisis APKL BUMD Klaster Pangan dalam Pengelolaan Ketahanan Pangan

\begin{tabular}{clllllc}
\hline No & \multicolumn{1}{c}{ SUBYEK } & A & P & K & L & Total \\
\hline 1 & $\begin{array}{l}\text { Strategi Aksi } \\
\text { Korporasi Ketahanan } \\
\text { Pangan }\end{array}$ & 4 & 5 & 5 & 3 & 17 \\
\hline 2 & $\begin{array}{l}\text { Strategi Perencanaan } \\
\text { Ketahanan Pangan }\end{array}$ & 4 & 4 & 3 & 2 & 13 \\
\hline 3 & $\begin{array}{l}\text { Strategi Evaluasi } \\
\text { Ketahanan Pangan }\end{array}$ & 4 & 3 & 3 & 3 & 13 \\
\hline & Sumber: data hasil analisis, 2021. & & & &
\end{tabular}

Dengan mendasarkan pada hasil analisis dengan metode APKL diperoleh hasil bahwa isu yang terpenting adalah isu Strategi Aksi Korporasi Ketahanan Pangan. Untuk itu subyek yang akan dianalisis lebih mendetail mendalam adalah Strategi Aksi Korporasi Ketahanan Pangan. Adapun bahwa operasional dalam hal ini adalah strategi aksi korporasi apa yang digunakan oleh BUMD Klaster Pangan dan usaha perdagangan dalam melakukan pengelolaan program ketahanan pangan di DKI Jakarta.
Identifikasi Faktor Eksternal dan Internal BUMD Klaster Pangan dalam Implementasi Program Ketahanan Pangan

Dengan mendasarkan hasil analisis APKL diperoleh hasil bahwa Strategi Aksi Korporasi merupakan strategi yang penting untuk ditindaklanjuti dalam implementasi program ketahanan pangan DKI Jakarta. Dengan demikian maka untuk analisis selanjtunya perlu diidentifikasi faktor eksternal dan internal BUMD Klaster Pangan dan usaha perpasaran dalam hal mengimplementasikan strategi aksi 
korporasi tersebut. Identifikasi faktor internal dan eksternal dapat diuraikan sebagai berikut.

Faktor Kekuatan
a. Kuatnya kredibelitas pemegang saham
b. Kuatnya landasan hukum operasional
c. Adanya jaminan ketercukupan modal
d. Kuatnya jaminan untuk governance
e. Terbukanya akses bisnis

Faktor Kelemahan
a. Terbukanya intervensi politik
b. Lemahnya independensi aksi korporasi
c. Kompleksitasnya birokrasi
d. Terdapatnya keharusan fungsi non- bisnis
e. Lambatnya merespon perubahan

Faktor Peluang

a. Tingginya peluang kesempatan bisnis

b. Tingginya tingkat kepercaayaan masyasrakat

c. Kuatnya dukungan pemeirntah

d. Terdapatnya captive market

e. Terbukanya kerja sama dengan pihak lain

\section{Faktor Ancaman}

a. Ketatnya persaingan bisnis dengan swasta

b. Cepatnya perubahan lingkunagn bsinis

c. Terdapatnya moral hazard Pengurus

d. Cepatnya perkembangan teknologi

e. Kurang kompetitivnya reward untuk para profesional

Selanjutnya dari hasil identifikasi faktor internal dan eksternal ini, dilakukan analisis dengan pendekatan matrik IFAS dan EFAS. Hal ini dimaksudkan agar memudahkan dalam memilih strategi implementasi. Selain itu, hal ini juga dimaksudkan untuk mendeteksi posisi strategi dalam diagram kartesius SWOT.

\section{Penyusunan Matrik Faktor Strategi Internal IFAS}

Dalam hal analisis dengan menggunakan matriks IFAS dan EFAS bahwa menurut Rangkuti (2001) bahwa setelah factor factor strategis internal suatu oraganisasai dididentifikasi maka dapat disusun table IFAS (Internal Factors Analysis Summary ) disusun unutk merumusakan factor factor strategi internal tersebut dalam kerangka kekuatan (strength) dan kelemahan (weakness). Selanjutnya dikatakan bahwa analisis ini dimaksudkan untuk mengidentifikasi berbagai faktor secara sistematis untuk dapat memaksimalkan kekuatan (strenghts) dan peluang (opportunities) namun secara bersamaan bisa meminimalkan kelemahan (weakness) dan ancaman (Subaktilah, Y; Nita K, dan Sih Y,2018).

Selanjutnya menurut Huda (2017) untuk pemberian peringkat dalam penyususn matarik EFAS dan IFAS menggunakan skala 1 (satu) sampai dengan 4 (empat). Skala 1 (rendah)4(tinggi) untuk kekuatan dan peluang. Sedangkan skala 4 (rendah)-1(tinggi) untuk kelemahan dan ancaman, namun karena tidak ada pembanding, maka nilai skala ditentukan berdasarkan prioritas 


\section{Jurnal Agristan}

Vol. 3 No. 2 - November 2021

Halaman. $172-190$

dari masing-masing situasi(misalnya

utama). Adapun ringkasannya adalah

skala 4 untuk peluang yang paling

sebagai berikut:

Tabel 2. Matrik Internal Factor Analysis Strategi (IFAS)

\begin{tabular}{|c|c|c|c|c|c|}
\hline No & Urutan & KATEGORI & BOBOT & RATING & SKORE \\
\hline 1 & \multicolumn{5}{|l|}{ Strength } \\
\hline & & Kuatnya kredibelitas pemegang & & & \\
\hline & a & saham & 0,25 & 4 & 1,00 \\
\hline & b & Kuatnya landasan hukum operasional & 0,19 & 4 & 0,75 \\
\hline & c & Adanya jaminan ketercukupan modal & 0,25 & 4 & 1,00 \\
\hline & d & Kuatnya jaminan untuk governance & 0,13 & 4 & 0,50 \\
\hline & e & Terbukanya akses bisnis & 0,19 & 4 & 0,75 \\
\hline \multirow[t]{9}{*}{2} & \multicolumn{2}{|c|}{ Weakness } & 1 & & 4,00 \\
\hline & a & Terbukanya intervensi politik & 0,24 & 3 & 0,71 \\
\hline & & Lemahnya independensi aksi & & & \\
\hline & b & korporasi & 0,18 & 4 & 0,71 \\
\hline & c & Kompleksitasnya birokrasi & 0,18 & 3 & 0,53 \\
\hline & & Terdapatnya keharusan fungsi non- & & & \\
\hline & d & bisnis & 0,24 & 3 & 0,71 \\
\hline & e & Lambatnya merespon perubahan & 0,18 & 3 & 0,53 \\
\hline & & & 1,00 & & 3,18 \\
\hline
\end{tabular}

Sumber: Data diolah, 2021

Sejalan dengan penyusunan Tabel

IFAS, pada penyusunan table EFAS

dilakukan dengan cara yang sama.
Adapun Tabel EFAS adalah sebagai berikut:

Tabel. 3 Tabel Matrik Eksternal Factor Analysis Strategi (EFAS)

\begin{tabular}{|c|c|c|c|c|c|}
\hline No & URUTAN & KATEGORI & BOBOT & RATING & SKORE \\
\hline \multirow[t]{8}{*}{3} & \multicolumn{5}{|c|}{ Opportunity } \\
\hline & \multirow[t]{2}{*}{ a } & Tingginya peluang kesempatan bisnis & 0,24 & 4 & 0,94 \\
\hline & & Tingginya tingkat kepercaayaan & & & \\
\hline & b & masyasrakat & 0,18 & 4 & 0,71 \\
\hline & c & Kuatnya dukungan pemeirntah & 0,24 & 3 & 0,71 \\
\hline & d & Terdapatnya captive market & 0,18 & 4 & 0,71 \\
\hline & \multirow[t]{2}{*}{ e } & Terbukanya kerja sama dengan pihak lain & 0,18 & 3 & 0,53 \\
\hline & & & 1,00 & & 3,59 \\
\hline \multirow[t]{8}{*}{4} & \multicolumn{5}{|c|}{ Threatens } \\
\hline & a & Ketatnya persaingan bisnis dengan swasta & 0,17 & 4 & 0,67 \\
\hline & b & Cepatnya perubahan lingkunagn bsinis & 0,17 & 3 & 0,50 \\
\hline & c & Terdapatnya moral hazard Pengurus & 0,22 & 2 & 0,44 \\
\hline & \multirow[t]{2}{*}{ d } & Cepatnya perkembangan teknologi & 0,17 & 3 & 0,50 \\
\hline & & Kurang kompetitivnya reward untuk para & & & \\
\hline & e & profesional & 0,17 & 2 & 0,33 \\
\hline & & & 1 & & 2,44 \\
\hline
\end{tabular}

Sumber: Data diolah, 2021 
Yurianto

\begin{tabular}{lrrl}
\hline \hline Selanjutnya & untuk & memudahkan & memudahkan dalam penggambaran \\
penyusunan & grand & strategy & diagram kartesius SWOT. Secara rinci \\
pengembangan dilakukan penyusunan & matriks Penggabungan IFAS dan EFAS \\
matrik penggabungan antara IFAS dan & adalah sebagai berikut.
\end{tabular}

EFAS. Aktivitas ini dilakukan untuk

Tabel 4. Matriks Penggabungan IFAS + EFAS

\begin{tabular}{llll}
\hline Sub Total Strength $=4,00$ & \multicolumn{2}{l}{ Sub Total Weakness $=3,18$} & 0,82 \\
\hline Sub Total Opportunity $=\mathbf{3 , 5 9}$ & Sub Total Threat & $=2,44$ & 1,15 \\
\hline Sub Total S + O & $=7,59$ & Sub Total W + T & $=5,62$
\end{tabular}

Sumber : data diolah 2021

Untukmenentukan strategy dalam Dengan dasar ini dibuat diagram pengembangan ekonomi digunakan hasil Kartesius sebagai berkut. penggabungan nilai IFAS dan EFAS.

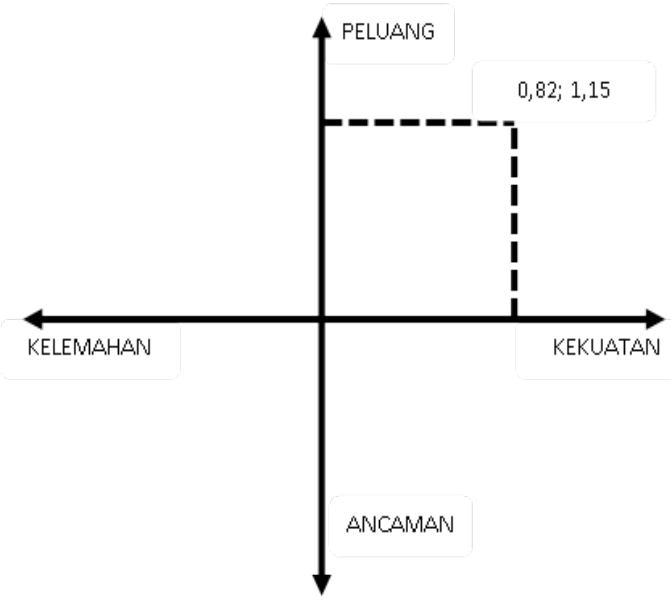

Gambar 2. Diagram Kartesius Strategi BUMD Klaster Pangan dan Usaha Perpasaran dalam Implementasi Program Ketahanan Pangan

Berdasarkan perhtungan ditemukan bahwa nilai total IFAS adalah 0,82 dan nilai total EFAS adalah 1,15. Kemudian dinyatakan oleh Anggraeni , Sunarti dan Mawardi (2017) bahwa strategy BUMD Klaster Pangan dalam pengembangan ekonomi yang perlu mendapat perhatian adalah berada pada
Kuadran I. Ini mempunyai pengertian bahwa situasi yang sangat menguntungkan. Pada strategy bahwa BUMD Klaster Pangan memiliki peluang dan sekaligus kekuatan untuk dapat mewujudkan tujuan pengembangan ekonomi. 
Dengan demikian maka strategy yang digunakan adalah straetgi S-O, menurut Anggraeni, Sunarti dan Mawardi (2017) bahwa Kuadran I : Merupakan situasi yang sangat menguntungkan. Perusahaan tersebut memiliki peluang dan kekuatan sehingga dapat memanfaatkan peluang yang ada. Strategi yang harus diterapkan dalam kondisi ini adalah mendukung kebijakan pertumbuhan yang agresif. (Growth oriented strategy).

\section{Analisis SWOT untuk BUMD Klaster} Pangan dalam Implementasi Program Ketahanan Pangan

Dalam pelaksanaan analisis dilakukan beberapa tahapan. Kajian ini menggunakan pendekatan kualitatif deskriptif dengan menggunakan SWOT.
Menurut istiqomah dan Irsad (2017) bahwa Analisis SWOT merupakan bagian dari proses perencanaan yang penting yang akan mempengaruhi proses pencapaian dan penentuan tujuan suatu institusi. Untuk itu penggunaan metode SWOT menjadi sangat penting.

Selanjutnya, sesuai dengan hasil analisis APKL, IFAS, dan EFAS maka analisis selanjutnya mengguankan Strategi Aksi Korporasi BUMD Klaster Pangan dalam implementasi program Ketahanan Pangan. Dalam hal ini strategi yang terpilih adalah strategi Growth atau Strategi Strength-Opportunity (strategi SO). Dengan menggunakan strategi tersebut diuraikan menjadi beberapa strategi, yaitu.

Tabel 5 . Matriks SWOT Pengembangan BUMD Klaster Pangan untuk Pengelolalan

Ketahanan Pangan

\begin{tabular}{|c|c|}
\hline & Strength \\
\hline EFAS & $\begin{array}{l}\text { a.Kuatnya kredibelitas pemegang } \\
\text { saham } \\
\text { b.Kuatnya landasan hukum } \\
\text { operasional } \\
\text { c.Adanya jaminan ketercukupan modal } \\
\text { d.Kuatnya jaminan untuk governance } \\
\text { e.Terbukanya akses bisnis }\end{array}$ \\
\hline $\begin{array}{l}\text { Opportunity } \\
\text { 1. Tingginya peluang } \\
\text { kesempatan bisnis } \\
\text { 2. Tingginya tingkat } \\
\text { kepercaayaan masyarakat } \\
\text { 3. Kuatnya dukungan } \\
\text { pemeirntah } \\
\text { 4. Terdapatnya captive } \\
\text { market } \\
\text { 5. Terbukanya kerja sama } \\
\text { dengan pihak lain }\end{array}$ & \begin{tabular}{|l} 
Strategi S-O \\
1. Peningkatan kolaborasi seluruh \\
pemangku kepentingan dengan \\
prinsip kemitraan \\
2. Peningkatan aksi bisnis dengan \\
focus digitalisasi aksi korporasi \\
3. Peningkatan Ekspansi Bisnis \\
Eksisting \\
4. Peningkatan Kerjasama Antar \\
Daerah
\end{tabular} \\
\hline
\end{tabular}

Sumber: data diolah 2021 
Karena strategi umumnya telah diidentifikasi, yaitu strategy growth maka diperlukan lagnkah untuk menyeleksi strategi operasionalnya. Bersadarakan hasil analisis ditemukan empat strategi operasional BUMD Klaster pangan dalam implementasi straetgi program pengelolaan kethanan pangan.

Penyusunan strategi ini menggunakan argumentative. Dengan mendasrakan pada kekautan dan peluang maka disuusn beberap strategi yang rasional dan argumentative. Hal ini selaras dengan pendapat Majone (1989) bahwa suatu model analisis argumentative tidak memberikan kepastian jawaban dari suatu pilihan tetapi hanya memberikan alasan yang rasional dan argumentative. Dengan dasar diperoleh empat strategi operasional kebijakan. Keempat strategi tersebut adalah sebagai berikut.

1. Peningkatan kolaborasi seluruh pemangku kepentingan dengan prinsip kemitraan

2. Peningkatan aksi bisnis dengan focus digitalisasi aksi korporasi

3. Peningkatan Ekspansi Bisnis Eksisting

4. Peningkatan Kerjasama Antar Daerah

Setelah prioritas strategi S-O ditentukan maka perlu dilakukan penapisan. Dalam hal ini penapisan dilakukan dengan menggunakan metode Mc Namara. Kriteria yang digunakan dalam hal ini adalah efisiensi, efektiitas dan kemudahan. Langkah selanjutnya adalah mencari alternatif yang paling tepat dalam implementasi program ketahanan pangan.

\section{Analisis Seleksi Strategi dengan}

\section{Pendekatan Mc. Namara}

Dalam hal ini digunakan Metode Mc Namara. Hal ini dikatakan oleh Nazlinawaty, Budi.H.; Ratu Q.A.(2021) bahwa Metode pragmatis untuk menemukan alternatif solusi dapat digunakan metode analisis Mc. Namara. Ditambahkan oleh Lihawa, Muhammad, dan Tri (2015) menyatakan bahwa langkah pertama dalam hal ini adalah dengan menentukan tiga (3) kriteria yang dinilai dari setiap alternatif Tiap kriteria diberikan skor nilai antara 1-5. Dari skore ini dijumlah dan pilih skore yang paling tinggi melalui Focus Group Discussian.

Penentuan suatu kebijakan memerlukan pemikiran yang serius. Menurut Winarno (2014) bahwa Perumusan masalah public tidak bisa dilepaskan daru dua hal. Pertama kelompok yang merumuskan maslaah tersetbut. Jadi kebijakan punblik sangat tergantaung dari siapa yang merumsukan. Yang kedua adalah menyangku komplektsitas dan sifat 
masalah. Tenttu untuk maaslaah yuang

lebih besar. Adapun Tabel Mc Namara komplek memerlukan perahatian yang adalah sebagai berikut.

Tabel 6. Tapisan Alternatif Solusi Mc.Namara Strategi Operasional BUMD Klaster Pangan dalam Imlementasi Program Ketahanan Pangan

\begin{tabular}{|c|c|c|c|c|c|c|}
\hline No & Stretagi Solusi & Efisiensi & Efektivitas & Kemudahan & Total & Ranking \\
\hline 1 & $\begin{array}{l}\text { Peningkatan } \\
\text { kolaborasi seluruh } \\
\text { pemangku } \\
\text { kepentingan dengan } \\
\text { prinsip kemitraan }\end{array}$ & 5 & 5 & 4 & 14 & 1 \\
\hline 2 & $\begin{array}{l}\text { Peningkatan aksi } \\
\text { bisnis dengan focus } \\
\text { digitalisasi aksi } \\
\text { korporasi }\end{array}$ & 4 & 4 & 3 & 11 & 3 \\
\hline 3 & $\begin{array}{l}\text { Peningkatan Ekspansi } \\
\text { Bisnis Eksisting| }\end{array}$ & 4 & 4 & 4 & 12 & 2 \\
\hline 4 & $\begin{array}{l}\text { Peningkatan } \\
\text { Kerjasama Antar } \\
\text { Daerah }\end{array}$ & 3 & 4 & 3 & 10 & 4 \\
\hline
\end{tabular}

Sumber: diolah dari data primer, 2021

Dengan mendasarkan analisis Mc. Namara sebagaimaan pada Tabel 4 diperoleh hasil bahwa strategi yang digunakan adalah strategi Peningkatan Kolaborasi Seluruh Pemangku Kepentingan dengan Prinsip Kemitraan . Sedangkan strategi opersioanal selanjutnya berturut turut adalah Peningkatan Ekspansi Bisnis Eksisting Peningkatan aksi bisnis dengan focus digitalisasi aksi korporasi dan terakhri adalah Peningkatan Kerjasama Antar Daerah. Dengan demikaian maka langkan stertegi oeprasianal dalam hal ini adalah Peningkatan Kolaborasi Seluruh
Pemangku Kepentingan Dengan Prinsip Kemitraan

\section{KESIMPULAN}

Dari kajian dan hasil analisis Strategi BUMD Kluster Pangan dalam implementasi Program Ketahana Pangan dengan Pendekatan APKL, IFAS, EFAS, SWOT dan Mc Namara diperoleh beberapa kesimpulan yang aggregative sebagai berikut.

1. Tingkat ketergantungan DKI Jakarta terhadap pangan sangat tinggi. Hal ini diebabkan karena ketersediaan lahan untuk produksi pangan sangat terbatas. Daerah 
yang mensupply pangan ke Jakarta antara lain Jawa Barat, Jawa Tengah, Jawa Timur, Sulawesi Selatan, Lampung, dan Sumatera Selatan. Sementara itu, daging sapi disuplai dari Jawa Tengah, Jawa Timur, Yogyakarta, Bali, Nusa Tenggara Timur, Lampung, dan impor dari luar negeri.

2. BUMD Klaster Pangan dan Usaha Perpasaran yang terdiri dari Perumda Pasar Jaya, PD Dharma Jaya dan PT Food Station Tjipinang mempunyai fungsi yang sentral dan strategis dalam implementasi pengelolalan program ketahanan pangan di DKI Jakarta.

3. Hasil analisis dengan menggunakan matriks EFAS dan IFAS dan dengan menggunakan diagram Kartesius diperoleh kesimpulan bahwa strategi yang tepat adalah adalah strategi Strength dan Opportunity (Strategy S-O). Strategi ini termasuk ke dalam strategi growth (Pertumbuhan).

4. Pilihan strategi yang tepat dari strategi Strength dan Opportunity ada 4 (empat ) Straretegi, yaitu Peningkatan kolaborasi seluruh pemangku kepentingan dengan prinsip kemitraan, Peningkatan aksi bisnis dengan focus digitalisasi aksi korporasi, Peningkatan
Ekspansi Bisnis Eksisting dan Peningkatan Kerjasama Antar Daerah

5. Dari keempat Stratetgi, dengan metode tapisan Mc. Namara ditemukan bahwa strategi yang paling tepat bagi BUMD Klaster Pangan dan Usaha Perpasaran dalam implementasi program Ketahanan Pangan di Jakarta adalah Strategi Peningkatan Kolaborasi Seluruh Pemangku Kepentingan Dengan Prinsip Kemitraan

\section{DAFTAR PUSTAKA}

Aisyah, Iseu Siti . (2020). Ketahanan Pangan Keluarga Di Masa Pandemi Covid 19. Jurnal Kesehatan komunitas Indonesia Vol 16 no 2 September 2020. Hal. 179-189.

Anggraeni, Pratiwi;Sunarti M. Kholid, dan Mawardi (2017). Analisis SWOT pada UMKM Keripik Tempe Amel Malang dalam Rangka Meningkatkan Daya Saing Perusahaan. Jurnal Administrasi Bisnis (JAB). Vol. 43 No.1 Februari2017.

Huda, Nurul (2017). Analisis Teknologi Informasi Pada Akademi Manajemen Informatika Dan Komputer Bina Sriwijaya Palembang Menggunakan Matrik EFAS dan IFAS. ISSN-P 24072192 Jurnal Teknik Informatika Politeknik Sekayu (TIPS) Volume VI, No. 1, Januari - Juni 2017 hal. 46-54.

Istiqomah dan Irsad Andriyanto. (2017). Analisis SWOT dalam Pengembangan Bisnis (Studi pada 
Sentra Jenang di Desa Wisata Kaliputu Kudus) . BISNIS, Vol. 5, No. 2, Desember 2017. Hal. 363382.

Lihawa, Cicilia, Muhammad Mansur, dan Tri Wahyu S. (2015). Faktor-faktor Penyebab Ketidaklengkapan Pengisian Rekam Medis Dokter di Ruang Rawat Inap RSI Unisma Malang Rumah Sakit Islam Unisma Malang. Jurnal Kedokteran Brawijaya, Vol. 28, Suplemen No. 2, 2015; hal.119-123.

Majone, Giandomenico, (1989). Evidence , Argument, And Persuasion In The Policy Process. Yale University Press. New Haven.USA.

Munir, Ningky Sasanti , (2017). Kesesuaian Pengasuhan Perusahaan Multibisnis: Studi Kasus Kelompok Bisnis "Media Group". Jurnal Ekonomi dan Bisnis. Volume 20 No. 2, Oktober 2017 ISSN 1979 - 6471. Hal. 253-273.

Novian, Dede R, Inggrid Trinidad Maha, dan Yudabbirul Arif. (2021). Optimalisasi Pembelajaran Digital Era Pandemi COVID-19. Jurnal Abdimas PHB Vol.4 No.1 Januari Tahun 2021 p-ISSN:2598-9030 eISSN:2614-056X .p.109-114.

Nazlinawaty, Budi.H.; Ratu Q.A.(2021). Solusi Lamanya Waktu Tunggu Pelayanan Farmasi di RSUD Cileungsi Kab Bogor Berdasarkan Telaah Jurnal. Muhammadiyah Public Health Journal E-ISSN : 2723-4266 Vol.1, No. 2, 31 Januari 2021.Hal.171-178.

Rangkuti, Freddy, (2001). Analisis SWOT Teknik Membedah Kasus Bisnis. Reorientasi Konsep Perencanaan Strategis untuk Menghadapi Abad 21. Gramedia. Jakarta 2003.
Subaktilah, Y; Nita K, dan Sih Y. ( 2018). Analisis Swot: Faktor Internal Dan Eksternal Pada Pengembangan Usaha Gula Merah Tebu (Studi Kasus di UKM Bumi Asih, Kabupaten Bondowoso). Jurnal Agroteknologi, Vol. 12 No. 02 (2018). Hal 107- 115.

Sugiyono (2011). Metode Penelitian Kuantitatifm dan Kualitatif dan R \& D. Alfabeta Bandung.

Winarno, Budi. (2014). Kebijakan Publik. Teori, Proses, dan Studi Kasus. CAPS. Depok Sleman Yogyakarta.

Undang undang No 18 tahun 2012 tentang Pangan

Peraturan Daerah Nomor 1 tahun 2018 tentang Rencana Pembangunan Jangka Menengah Daerah Provinsi DKI Jakarta 2017 - 2022. 